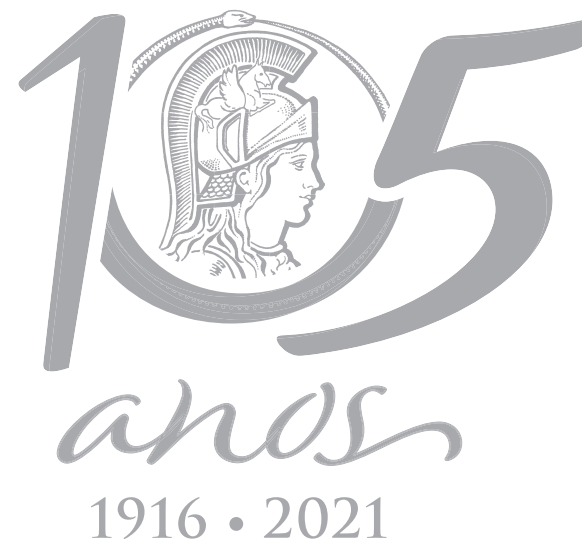

$1916 \cdot 2021$

\title{
Carcass and commercial cuts yields of caiman (Caiman crocodilus yacare) farmed in a ranching system in the Brazilian Pantanal
}

\author{
NATALIA B.C. MEDEIROS, MARCOS RODRIGUES, DRAUSIO H. MORAIS \& MARILIA \\ D. NUNES-RODRIGUES
}

\begin{abstract}
Given the growing use of alternative sources of protein, studies on the commercial viability of amazonians wild species, based on the yield of their carcass, are still scarce in the literature. To evaluate yields of carcass and commercial cuts of caiman meat (Caiman crocodilus yacare), according to sex and weight categories, besides analyzing their revenue. Thirty animals in termination phase were selected, separated by sex and weighed. The cuts analyzed was of $59.7 \%$ in relation to total live weight, and of $70.7 \%$ in relation to the carcass. Regarding the yields of the cuts, the average weight difference in detriment to the sex of the animals was minimal, however, in the weight categories, animals classified as intermediate and heavy (5.9-9.1 kg) resulted in higher cut weights $(p<0.01)$ and consequently in revenue for most of the meat cuts (66.7\%), especially for tail, back, and sirloin fillets. It can be concluded that the carcass yield of caiman is high, and that heavy animals resulted in higher yields of prime cuts, emphasizing the need to carry out studies that prioritize the cost/benefit ratio taking into account the age and weight of the animals.
\end{abstract}

Key words: Captivity, crocodilians, meat, meat processing, production.

\section{INTRODUCTION}

The caiman, Caiman crocodilus yacare (DAUDIN, 1802), popularly known as Jacaré do Pantanal, can be found in the lowlands of North and East of Bolivia, west of Brazil along the rivers Guaporé, Madeira, Paraná, and Paraguai, and North of Argentina, which demonstrates a variable environmental spectrum of the species (Campos et al. 2010). Caimans are naturally highly abundant in the Brazilian Pantanal, with densities of more than 100 individuals $/ \mathrm{km}^{2}$ distributed along the floodplains (Farias et al. 2013), which is a factor that certainly enabled enterprises and farmers to first implement the exploitation of wild caimans in Brazil. The supply chain of caimans raised in captivity is growing in
Brazil since 1990, when IBAMA regulated the use of farmed alligators for commercial purposes (Ordinance No 126 1990).

Caiman farming has high economic potential due to the variety of products, like the skin (converted into leather), meat, and even the urine that is used as fixator in perfumery (Carreira \& Sabbag 2015). The commercialization of caiman meat, is an activity complementary to the commercialization of skin, and is traditional in the Pantanal (Seidl et al. 2001), resulting in greater aggregated value since caiman meat is a great source of protein for humans (caiman originating from captivity presented $23.93 \%$, and animals originating from natural habitat $21.88 \%$ of protein), with a low amount of intramuscular fat (0.8\%) (Simoncini et al. 2020), 
used as an excellent alternative in low-fat diets due to reduced cholesterol rates (animals from captivity $51.23 \%$, and from natural habitat $38.83 \%$ of cholesterol $(\mathrm{mg} / 100 \mathrm{~g})$ ), and high rates of polyunsaturated fatty acids (linoleic acid C18:2w6 (12.97\%) and arachidonic acid C20:4w6 (6.95\%)) (Vicente Neto et al. 2006), compared to meat of domestic animals (Hoffman 2008, Paulino et al. 2011, Vicente Neto et al. 2007). Caiman meat presents a healthy fatty acid profile for human consumption and an ideal ratio fatty acid, omega 6 / fatty acid, omega 3 (Piña et al. 2016). However, even with all these qualities, significant amounts of meat are still lost during processing because of the lack of investment in technology by the meat processing units, specialized slaughterhouses for the caiman's meat (Canto et al. 2014). However, in some countries there are farms that process the waste (useless product, strips and scraps of noble cuts of meat) as raw materials for the production of meat meal (Andriguetto et al. 1999, Ockerman \& Hansen 1994), an alternative considered as an important nutritional ingredient in the preparation of pet food, this being a food supply rich in nutrients (Andriguetto et al. 1999, Ockerman \& Hansen, 1994, Pardi et al. 1994).

Given the growing use of alternative sources of protein, studies on the commercial viability of amazonians wild species, based on the yield of their carcass, are still scarce in the literature. The study of the use of carcasses of alligators farmed for commercial purposes, which takes into account the relation between the live weight prior to slaughtering with the weight after processing, serves as a base for industrial processing by providing information to meat processors, consumers (Fernandes et al. 2017), and as a tool for analyses of commercial viability (Carreira \& Sabbag 2015).

This study aimed to: (a) evaluate the yields of carcass and commercial cuts of caiman meat in relation to sex and weight categories of the animals; and (b) economically analyze the alligator meat products in comparison to carcass sold by a cooperative in Pantanal.

\section{MATERIALS AND METHODS}

\section{Area description and samples}

This study was conducted in the commercial cooperative of caiman farmers 'Cooperativa dos Criadores de Jacaré do Pantanal - Coocrijapan', located at the border zone of the Brazilian Legal

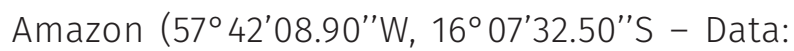
SIRGAS2000), at the municipality of Cáceres, Southwest of Mato Grosso State, Brazil, licensed by IBAMA-MT (1/51/92/ 0197-0).

Thirty animals (15 females and 15 males) of the caiman Caiman crocodilus yacare (Jacaré do Pantanal), were used to study the yields of carcass and commercial cuts. The animals were farmed in a ranching system, that is to say, that the eggs are collected in nature and raised on the farm, fed on viscera bovine and ration with high protein level (> $47 \%$ of crude protein), provided daily. The animals were measured with tape measure, and weigh with analogue scale Pesola ${ }^{\circledR}$, obtaining the measurements and live weight individually. The selected were based on their average length of $1.30 \mathrm{~m}$, belonging to the same offspring - Catch 2014, all animals if three years old.

The animals grouped in three categories: light, intermediate, and heavy; each group with 10 animals, with live weight of 4.1-5.9 kg (kilogram); 5.9-6.9 kg; and 7.0-9.1 kg, respectively, housed in concrete pools (alligator confinement bays), with Fifty Percent of the pool area had $10 \mathrm{~cm}$ deep water and the other extreme fifty percent was dry, organized according to an offspring.

Animals were slaughtered in slaughter house inside the ranch, by of the process of insensibilizing by means of a pneumatic pistol, 
guaranteeing the unconsciousness, and after suffering a concussion due to the stunning, the animal is allocated in a support table, and the cut is carried out at the end of the neck, leaving exposed cervical vertebrae, where, with by introducing a wire, the nerves connected the spinal cord wills be broken, ceasing the movements of the animal, and later, will be hoisted so that the blood is drained, at which moment the animal is definitely slaughtered. After this process, the skin, feet, head and viscera will be removed, so that the carcass is washed and inspected, and sent to the clean processing area, where the carcass weighing will be carried out, and storage in a chilling chamber per fence of four hours before processing (1-5 ${ }^{\circ}$ C). The slaughtering was carried out under strict sanitary conditions.

It was taken the weight of the products and byproducts after slaughter (skin, head, legs, and viscera), of the meat (weight of the whole carcass), and of nine cuts commercially sold by the cooperative: scraps I, scraps II, boned thigh, strips, tail fillet, back fillet, sirloin fillet, mignon fillet, and tail tip (Figure 1).

The slaughterhouse divides the tail cut in two cuts, tail fillet and tail tip, producing 11 cuts. The cuts thigh and upper thigh were not made during this study because of low demand, being substituted by the boned thigh cut, corresponding to the sum of those two cuts boneless (thigh + upper thigh) which totalized in nine cuts for the present study.

\section{Yields (\%)}

The yields were determined in two ways according to live weight of the animal and in relation to carcass weight (Equations one and two):

$$
\text { PYlw }=\frac{\mathrm{PW}}{\mathrm{LW}} \times 100
$$

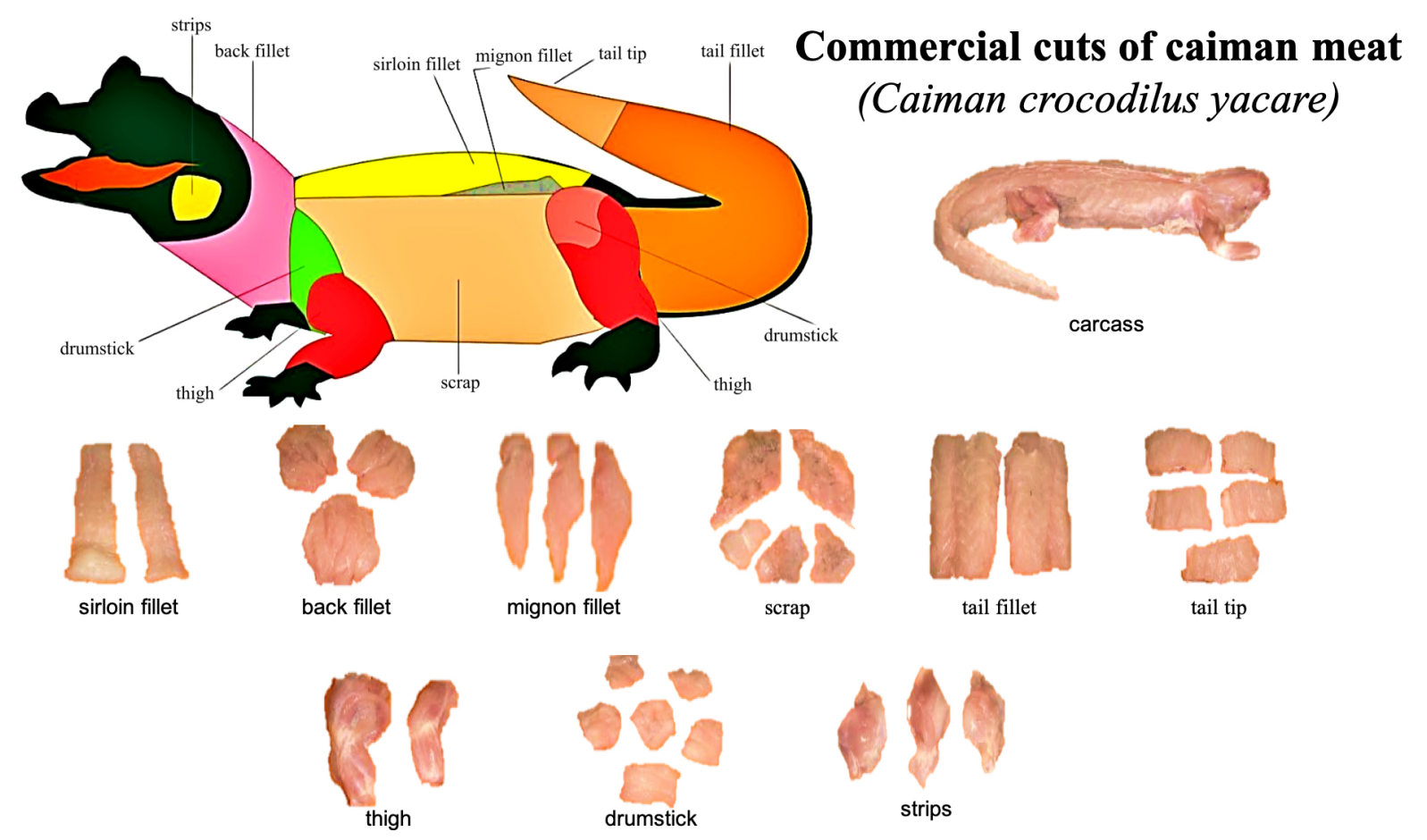

Figure 1. Commercial cuts of Caiman crocodilus yacare meat developed by the commercial cooperative of caiman farmers 'Cooperativa dos Criadores de Jacaré do Pantanal - Coocrijapan. Source: COOCRIJAPAN 2009. 
In which:

PYlw: Products yields (carcass, cut, etc.) based on live weight;

Pw: Product weight (carcass, cut, etc.);

LW: Live weight of the animal.

$Y C c w=\frac{\mathrm{Wc}}{\mathrm{CW}} \times 100$

In which:

YCCW: Yield of commercial cuts based on carcass weight;

Wc: Weight of commercial cut;

CW: Carcass weight.

As for the financial income, they were obtained by multiplying the amount charged per $\mathrm{kg}$ of commercial alligator cut (prices updated at the time of experiment), by the average weight of alligator cuts slaughtered, broken down by weight category and sex.

\section{Statistical analysis}

To analyze the effects of sex and weight prior to slaughter in yields and components of caiman carcass, the collected and plotted data were submitted to analysis of variance in the software GraphPad Prism v.7.03, followed by Tukey's HSD (honestly significant difference) test with $5 \%$ of significance.

The procedures adopted in this study were approved by the Ethics Committee of the Federal Rural University of Amazonia (23084.03613/2018-59).

\section{RESULTS}

The weight range of the animals observed in this study was from 4.1 to $9.1 \mathrm{~kg}$, with average of $6.5 \mathrm{~kg}$ $( \pm 1.31)$ for both sexes.

For carcass yield, the average of females was $58.9 \%( \pm 3.86)$, and of males $60.4 \%( \pm 2.73)$, not showing significant differences $(p<0.05)$. The average yield of the products skin, viscera, head, and legs were of $20.2 \%( \pm 1.14), 9.8 \%( \pm 0.83), 6.1 \%$ $( \pm 0.38)$, and $2.0 \%( \pm 0.17)$ for females, and of $20.3 \%( \pm 1.21), 10.0 \%( \pm 0.87), 6.0 \%( \pm 0.44)$, and $2.0 \%( \pm 0.20)$ for males, respectively. The yields and weights of carcass of the cuts analyzed did not show differences in relation to sex $(p<0.05)$.

As for average weight of commercial cuts 'Table I', males showed to be superior in all cuts, which was reflected in the sum of the weight of the cuts (SC) 'Table II', even though more was lost in the boning process compared to females.

For the weight categories, the yields did not show significant differences $(p<0.05)$ for light animals $(59.2 \% \pm 0.35)$, intermediate $(61.3 \% \pm$ 0.29), and heavy $(58.6 \% \pm 0.39)$.

The average yields of skin, viscera, head, and legs were $21.1 \%( \pm 0.97), 10.1 \%( \pm 0.73), 6.4 \%( \pm$ $0.33)$, and $2.2 \%( \pm 0.20)$ for light animals; $20.0 \%$ $( \pm 0.81), 10.0 \%( \pm 1.12), 6.0 \%( \pm 0.29)$, and $1.9 \%$ $( \pm 0.11)$ for intermediate animals; and $19.3 \%( \pm$

Table I. Analysis of the yield of commercial cuts in relation to animals' carcass (\%), and average weight of the cuts of slaughtered caiman, separated by sex (females and males).

\begin{tabular}{|c|c|c|c|c|}
\hline Cuts & Females, $\mathbf{~ g g}$ & $\mathbf{A Y} / \mathbf{C}, \mathbf{\%}^{\mathbf{1}}$ & Males, $\mathbf{~ k g}$ & $\mathbf{A Y} / \mathbf{C}_{\mathbf{~} \mathbf{\%}^{\mathbf{1}}}$ \\
\hline Strips & $0.1 \pm 0.04$ & 2.7 & $0.1 \pm 0.03$ & 2.5 \\
\hline $\begin{array}{c}\text { Boned } \\
\text { thigh }\end{array}$ & $0.3 \pm 0.08$ & 7.9 & $0.3 \pm 0.08$ & 7.7 \\
\hline Tail tip & $0.2 \pm 0.05$ & 4.1 & $0.2 \pm 0.04$ & 3.9 \\
\hline Scraps I & $0.3 \pm 0.08$ & 7.2 & $0.3 \pm 0.07$ & 7.3 \\
\hline Scraps II & $0.3 \pm 0.13$ & 7.6 & $0.3 \pm 0.15$ & 7.5 \\
\hline Tail fillet & $0.7 \pm 0.21$ & 19.0 & $0.7 \pm 0.20$ & 18.4 \\
\hline $\begin{array}{c}\text { Sirloin } \\
\text { fillet }\end{array}$ & $0.4 \pm 0.11$ & 11.8 & $0.4 \pm 0.08$ & 11.3 \\
\hline Back fillet & $0.3 \pm 0.07$ & 8.3 & $0.3 \pm 0.07$ & 8.3 \\
\hline $\begin{array}{c}\text { Mignon } \\
\text { fillet }\end{array}$ & $0.1 \pm 0.03$ & 2.9 & $0.1 \pm 0.03$ & 2.8 \\
\hline AVERAGE & $2.7 \pm 0.08$ & 71.6 & $2.8 \pm 0.08$ & 69.8 \\
\hline
\end{tabular}

${ }^{1}$ Average yield/carcass (\%). 
0.82), 9.3\% ( \pm 0.46$), 5.7 \%( \pm 0.25)$, and 1.9\% ( \pm 0.10$)$ for heavy animals, respectively. Light animals showed greater yields of skin, viscera, head, and legs (39.8\%) even with reduced live weight.

The nine commercial cuts analyzed showed variable yields in relation to weight category. For most of the cuts (66.7\%), heavy animals, followed by intermediate, showed greater average weight. For the cut Scraps II, heavy and light animals showed weight greater than intermediate animals $(p<0.05)$. However, the cuts scraps and tail tip did not show significant difference in any of the three weight categories 'Table III'.

The losses (bones and remnants of meat on the bones), which was the difference between the carcass weight and the sum of the cuts, were of $0.9 \mathrm{~kg}( \pm 0.13), 1.2 \mathrm{~kg}( \pm 0.35)$, and $1.3 \mathrm{~kg}( \pm$ 0.29), for light, intermediate, and heavy animals, respectively.

The results of the analysis of the use of meat cuts of caiman was of $59.7 \%$ in relation to total live weight, and of $70.7 \%$ in relation to carcass, comprising the ratio of the sum of the meat yields to the weight of cooled carcass. For the financial use by animal, it could be observed that the cuts tail fillet, sirloin fillet, back fillet, and boned thigh assure more profit by animal since heavy males stand out in most of the cuts 'Table IV'.

Table II. Weight from animal processing of the caimans separated by sex (females and males).

\begin{tabular}{|c|c|c|}
\hline Weight & Females, $\mathbf{k g}$ & Males, kg \\
\hline Live weight (LW) & 6.4 & 6.6 \\
\hline Carcass Weight (CW) & 3.8 & 4.0 \\
\hline Sum of the cuts (SC) & 2.7 & 2.8 \\
\hline Losses $^{1}$ (L) & 1.1 & 1.2 \\
\hline
\end{tabular}

${ }^{1}$ Difference between the carcass weight and sum of the cuts: bones and remnants of meat on the bones.

Table III. Analysis of yield of commercial cuts in relation to animals' carcass (\%), and average weight of cuts of slaughtered caimans, separated by weight category.

\begin{tabular}{|c|c|c|c|c|c|c|c|}
\hline Cuts & Light, kg & $\mathrm{AY} / \mathrm{C}, \%^{1}$ & Intermediate, kg & $A Y / C, \%^{1}$ & Heavy, kg & $A Y / C, \%^{1}$ & Significance \\
\hline Strips & $0.1 \pm 0.021$ & 3.0 & $0.1 \pm 0.03$ & 2.6 & $0.1 \pm 0.04$ & 2.4 & ns \\
\hline Boned thigh & $0.2 \pm 0.05$ & 7.5 & $0.3 \pm 0.06$ & 8.2 & $0.4 \pm 0.07$ & 7.7 & * \\
\hline Tail tip & $0.1 \pm 0.03$ & 4.4 & $0.2 \pm 0.05$ & 4.2 & $0.2 \pm 0.05$ & 3.7 & ns \\
\hline Scraps I & $0.2 \pm 0.04$ & 6.8 & $0.3 \pm 0.04$ & 7.5 & $0.3 \pm 0.06$ & 7.3 & * \\
\hline Scraps II & $0.2 \pm 0.08$ & 8.3 & $0.2 \pm 0.15$ & 5.6 & $0.4 \pm 0.08$ & 8.7 & * \\
\hline Tail fillet & $0.5 \pm 0.07$ & 17.4 & $0.8 \pm 0.14$ & 19.0 & $0.9 \pm 0.17$ & 19.3 & * \\
\hline Sirloin fillet & $0.3 \pm 0.06$ & 11.7 & $0.5 \pm 0.07$ & 11.8 & $0.5 \pm 0.06$ & 11.1 & * \\
\hline Back fillet & $0.3 \pm 0.05$ & 8.5 & $0.3 \pm 0.05$ & 8.5 & $0.4 \pm 0.06$ & 8.1 & * \\
\hline Mignon fillet & $0.1 \pm 0.02$ & 2.7 & $0.1 \pm 0.03$ & 3.1 & $0.1 \pm 0.02$ & 2.8 & * \\
\hline Total (AVERAGE) & $2.1 \pm 0.05$ & 70.3 & $2.8 \pm 0.07$ & 70.4 & $3.3 \pm 0.07$ & 71.1 & - \\
\hline
\end{tabular}

${ }^{1}$ Average yield/carcass (\%).

Significance: ns: not significant; * $p<0.05$. 
Table IV. Analysis of the revenue of commercial cuts in Brazilian currency (R\$) of slaughtered caimans, separated by sex category and weight category.

\begin{tabular}{|c|c|c|c|c|c|}
\hline & \multicolumn{2}{|c|}{ Sex } & \multicolumn{3}{c|}{ Weight category } \\
\hline Cuts & Females & Males & Light & Intermediate & Heavy \\
\hline Strips & $5.0 \pm 1.94$ & $5.1 \pm 1.41$ & $4.5 \pm 1.03$ & $5.1 \pm 1.77$ & $5.6 \pm 2.04$ \\
\hline Boned thigh & $16.5 \pm 4.58$ & $17.2 \pm 4.60$ & $12.5 \pm 2.94$ & $18.2 \pm 3.20$ & $19.9 \pm 3.79$ \\
\hline Tail tip & $6.6 \pm 2.11$ & $6.7 \pm 1.91$ & $5.6 \pm 1.13$ & $7.0 \pm 2.25$ & $7.4 \pm 2.03$ \\
\hline Scraps I & $11.5 \pm 3.42$ & $12.4 \pm 2.98$ & $8.7 \pm 1.65$ & $12.7 \pm 1.91$ & $14.5 \pm 2.55$ \\
\hline Scraps II & $12.2 \pm 5.37$ & $12.7 \pm 6.26$ & $10.5 \pm 3.50$ & $9.5 \pm 6.42$ & $17.3 \pm 3.52$ \\
\hline Tail fillet & $49.1 \pm 14.53$ & $50.6 \pm 13.95$ & $35.7 \pm 4.89$ & $51.9 \pm 9.30$ & $61.9 \pm 11.60$ \\
\hline Sirloin fillet & $30.5 \pm 7.40$ & $30.9 \pm 5.64$ & $24.1 \pm 4.36$ & $32.4 \pm 4.60$ & $35.7 \pm 3.92$ \\
\hline Back fillet & $21.6 \pm 5.13$ & $22.8 \pm 4.69$ & $17.6 \pm 3.14$ & $23.2 \pm 3.21$ & $25.8 \pm 4.06$ \\
\hline Mignon fillet & $7.6 \pm 2.22$ & $7.7 \pm 2.13$ & $5.6 \pm 1.35$ & $8.4 \pm 1.75$ & $8.9 \pm 1.75$ \\
\hline AVERAGE & $160.7 \pm 39.87$ & $166.2 \pm 34.22$ & $124.9 \pm 16.40$ & $168.5 \pm 19.05$ & $197.1 \pm 27.40$ \\
\hline Whole & $207.5 \pm 45.48$ & $220.4 \pm 40.04$ & $165.1 \pm 19.12$ & $219.6 \pm 15.84$ & $257.2 \pm 21.75$ \\
\hline
\end{tabular}

When comparing the revenue in relation to the meat processing, commercialized in cuts or the whole carcass, it can be observed that the difference among the animals regarding sex was less than regarding weight, highlighting heavier animals and their profit as whole carcass.

\section{DISCUSSION}

The study on the effects of sex and weight prior to slaughter in yields and components of alligators' carcass, aims at reinforcing the commercial viability of the meat, establishing criteria for slaughtering based on characteristics pertinent to animal category, rather than based solely on the leather circumference.

However, it is possible to suggest at production level, based on the results of carcass yields and their respective average deviation, that animals belonging to the categories light and intermediate $(4.1-6.9 \mathrm{~kg}$ ) result in superior carcass yields compared to heavier animals in relation to live weight.
Light animals showed better yields of byproducts (skin, viscera, head, and legs), even with reduced live weight, which can be explained by the constancy of proportionality of average weight of these products in the three weight categories. Once all animals were adults, they certainly reached the maximum development at the level of anatomy and physiology of those body components.

The losses showed to be directly proportional to live weight, carcass weight, and sum of the cuts. According to Fernandes et al. (2017), the yields from the processing of commercial meat cuts depend mainly on the skills of the operator of the cuts, followed by the constants weight and age of the animal. Therefore, these are variables that must be taken into consideration in future studies.

Studies on yields of meat cuts of caiman (Fernandes et al. 2017, Girardi et al. 2008) have been developed specially in regard to the live weight of the animals, although only four cuts are the most studied (tail, sirloin fillet, back fillet, and thigh). The 'Table $\mathrm{V}$ ' is a compilation 
Table V. Yields in relation to the live weight of the animals (compilation).

\begin{tabular}{|c|c|c|c|c|c|}
\hline Live weight, kg & Tail, \% & Sirloin fillet, \% & Back fillet, \% & Thigh, \% & Reference \\
\hline $3.22-5.78$ & 15.3 & 7.8 & 8.0 & 16.9 & Girardi et al. (2008) \\
\hline 3.58 & 16.4 & 5.3 & 4.7 & 5.2 & Fernandes et al. (2017) \\
\hline 5.07 & $12.9^{1}$ & 6.9 & 5.0 & $4.5^{2}$ & Current study \\
\hline 6.51 & $14.2^{1}$ & 7.3 & 5.2 & $5.0^{2}$ & Current study \\
\hline 7.98 & $13.5^{1}$ & 6.5 & 4.7 & $4.5^{2}$ & Current study \\
\hline
\end{tabular}

${ }^{1}$ Cuts currently used: tail fillet and tail tip summed for yields; ${ }^{2}$ Boned thigh.

of published data and the data of this current study, presenting the yield in relation to live weight of slaughtered caimans for the four main commercial meat cuts of caimans.

According to Girardi et al. (2008), the high yield of the tail is explained by its muscle growth that is more accelerated compared to other tissues. The tail has an important locomotion function for the animal in its habitat, assuring agility at the moment of food capture in nature.

The carcass yield values (in relation to live weight of the animal), obtained in the present study was higher (59.7\%) when compared to other species of crocodilians. Hoffman (2008) observed yields of $56.5 \%$ for Crocodylus niloticus (crocodile); Cossu et al. (2007) reported 54.1\% for Caiman latirostris; and Kluczkovski Junior et al. (2015) reported 57\% for Melanosuchus niger (natural environment). However, the results obtained in the present study were lower than for the existing data on Alligator mississippiensis, which is $62.3 \%$ (Moody et al. 1980). As for the same species, Romanelli \& Felicio (1999), observed 59.5\% for Caiman yacare.

Even though crocodilians show considerable phenotypic similarity (Kluczkovski Junior et al. 2015), the comparison among existing data is difficult. This fact is due to the differences in standardizing the cuts, general management, hormonal alterations, and even the use of distinct species for farming (Kluczkovski Junior et al. 2015, Hoffman et al. 2000).

Caiman meat shows yields (in relation to carcass weight) superior (70.7\%) to domesticated species used for meat production, like swine (62.8\%) and cattle (28.0\%) (Silva et al. 2016). This fact may be due to the better use of noble cuts and less valued cuts (scraps I and II) for caimans, besides their less density of fat and bones, which is easily visualized.

Given the information provided in this study, it is still possible to infer that animals between the categories intermediate and heavy (5.9-9.1 $\mathrm{kg}$ ) reflect in greater revenue for slaughterhouses since, as observed before, heavier animals tend to have heavier carcasses standing out in relation to noble cuts, like fillets. However, the threshold of advantages is still unknown because heavier animals demand more farming time and consequently more costs with feeding and maintenance. Therefore, a deeper study on the viability of maintaining such heavy animals in production must be carried out taking into account analysis of the relation cost/benefit. Alternative uses to increase the yield and revenue of caiman meat processing units are available, including sausage and non-sausage products, preserved meat and mortadella, all with favorable acceptance (Morais et al. 2013, Romanelli et al. 2002). 
Family farmers, indigenous peoples, quilombolas and other traditional communities make use of alligator meat, as a resource widely available in several parts of Brazil, both for their own subsistence, and for marketing through fairs and restaurants. However, public policies must invest in raising awareness of the importance of maintaining biodiversity, so that nature is able to offer healthy food to the population, including alligator meat, and as a counterpart, to fight rural poverty.

In the present study, the carcass yield in relation to sex showed high dispersion of values from the average (standard deviation), which is possibly due to the variable measures of live weight, reflecting the lack of evenness of the catch in the farming system, which may pose risk to the sustainability of the activity, like possible problems related to agonistic behavior that may affect adequate zootechnical development of animals. Moreover, possible divergences related to ration consumption can affect the feeding performance of animals belonging to the same catch.

This way, it can be suggested a stratification of the catches, based not only on maintaining animals of similar offspring, but also on making the catches uniform regarding weight and sex categories, aiming at having more homogeneous groups.

\section{CONCLUSION}

It can be concluded that the carcass yield of caimans is elevated and do not differ statistically in function of sex or weight.

Regarding the commercial cuts, the difference among the averages of weights for the sexual categories was minimum. However, for the weight categories, heavy animals resulted in higher yields of noble cuts. Nevertheless, more studies must be carried out, prioritizing specially the ratio cost/benefit taking into consideration the age and weight of the animals.

As for revenue, it was possible to infer that the commercialization of whole carcasses would bring better financial results to producers, mainly for heavier carcasses. However, since this form of commercialization is not appealing to consumers, the commercialization in cuts is the most economically viable.

The data collected in this study reliably enrich the literature about the marketing of exotic meat, since it is not based on packing list. However, more studies need to be carried out on sanitary management of meat, always looking for safer food for the population.

The present study can be the start of a shared database, periodically updated, that would facilitate the comparison between intra and inter productive systems, as well as the creation of future projects. Such database could even be used for other commercialized alligator species, like Caiman latirostris (Jacaré do papo amarelo). Furthermore, the results of this study can help enterprises of breeding and farming of caimans to make better decisions that can bring more yields, making them more efficient in the marketing.

\section{Acknowledgments}

The authors thank the farm COOCRIJAPAN, for providing the execution of this experiment.

\section{REFERENCES}

ANDRIGUETTO JM, PERLY L, MINARDI I, GAMAEL A, FLEMMING JS, SOUZA GA \& BONA FILHO A. 1999. Nutrição animal. São Paulo: Nobel, 395 p.

CAMPOS Z, LLOBET AQ, PIÑA CI \& MAGNUSSON WE. 2010. Yacare Caiman Caiman yacare. In: Manolis SC and C Stevenson C. (Eds) Crocodiles. Status Survey and Conservation Action Plan. Crocodile Specialist Group: Darwin, p. 23-28. 
CANTO ACVCS, LIMA BRCC, SUMAN SP, LAZARO CA, MONTEIRO MLG, CONTE-JUNIOR CA, FREITAS MQ, CRUZ AG, SANTOS EB \& SILVA TJP. 2014. Physico-chemical and sensory attributes of low-sodium restructured caiman steaks containing microbial transglutaminase and salt replacers. Meat Sci 96(1): 623-632.

CARREIRA LBT \& SABBAG OJ. 2015. Economic aspects of production of Caiman crocodilus yacare. An Acad Bras Cienc 87: 495-502.

COOCRIJAPAN. 2009. Presentation of the Coocrijapan's website. http://www.coocrijapan.com.br/23_tipos_ cortes.asp.

COSSU ME, GONZÁLEZ OM, WAWRZKIEWICZ M, MORENO D \& VIEITES MC. 2007. Carcass and meat characterization of "yacare overo" (Caiman latirostris) and "yacare negro" (Caiman yacare). Braz J Vet Res Anim Sci 44.

FARIAS IP, MARIONI B, VERDADE LM, BASSETTI L, COUTINHO ME, MENDONÇA SHST, VIEIRA TQ, MAGNUSSON WE \& CAMPOS Z. 2013. Avaliação do risco de extinção do jacaré-do-pantanal Caiman yacare (Daudin, 1802) no Brasil. Biodivers Bras 3(1): 21-30.

FERNANDES VRT, SOUZA MLR, GASPARINO E, COUTINHO ME, VISENTAINER, JV, BÉRGAMO AS \& GOES ESR. 2017. Commercial cuts of Pantanal caiman meat according to sex. Cienc Rural 47(2).

GIRARDI WC, DA SILVA JA \& TORAL FLB. 2008. Efeito do peso ao abate do jacaré-do-Pantanal (Caiman yacare, Daudin 1802) sobre rendimentos de cortes comerciais da carcaça. In: Evangelista AR, Leite GG, Queiroz AC and Pereira JC (Eds). 45 Reunião Anual da Sociedade Brasileira de Zootecnia. Lavras, MG: SBZ, p. 1-3.

HOFFMAN LC. 2008. The yield and nutritional value of meat from African ungulates, camelidae, rodents, ratites and reptiles. Meat Sci 80(1): 94-100.

HOFFMAN LC, FISHER PP \& SALES J. 2000. Carcass and meat characteristics of the Nile crocodile (Crocodylus niloticus). J Sci Food Agric 80(3): 390-396.

KLUCZKOVSKI JUNIOR A, KLUCZKOVSKI AM, MORONI FT, MARKENDORF F \& INHAMUNS AJ. 2015. Carcass yield and proximate composition of black caiman (Melanosuchus niger) meat. IJFA 7: 47-53.

MOODY MW, COREIL PD \& RUTLEDGE JE. 1980. Alligator meat: yields, quality studied. Louisiana Agriculture 24(1): 14-15.

MORAIS CSN, MORAIS NN, VICENTE-NETO J, RAMOS EM, ALMEIDA J, ROSEIRO C \& BRESSAN MC. 2013. Mortadella sausage manufactured with Caiman yacare (Caiman crocodilus yacare) meat, pork backfat, and soybean oil. Meat Sci 95(2): 403-411.
OCKERMAN HW \& HANSEN CL. 1994. Industrialización de Subprodutos de origem animal. Zaragoza: Editorial Acribia, 387 p.

ORDINANCE N 126. 1990. Ordinance No 126, February 1990, Pub. L. No. 126, 1 (1990). IBAMA.

PARDI MC, DOS SANTOS IF, DE SOUZA ER \& PARDI ES. 1993. Ciência, Higiene e Tecnologia de Carne.. Goiânia: Eduff, $1110 \mathrm{p}$.

PAULINO FO, SILVA TJP, FRANCO RM, MÁRSICO ET, CANTO ACVCS, VIEIRA JP \& PEREIRA APAAS. 2011. Processamento e características de qualidade de hambúrguer de carne de jacaré-do-pantanal (Caiman crocodillus yacare). Rev Bras Med Vet 18(2/3): 129-132.

PIÑA CI, LUCERO L, SIMONCINI MS, PETERSON G \& TAVELLA M. 2016. Lipid profi le of yacarés overo meat fed with diets enriched with flax seeds. Zootec Trop 34(2): 25-33.

PRICE JF \& SCHWEIGERT BS. 1994. Ciência de la carne y de los produtos carnicos. Zaragoza: Editorial Acribia, 581 p.

ROMANELLI PF, CASERI R \& LOPES FILHO JF. 2002. Meat processing of pantanal alligator (Caiman crocodilus yacare). Food Sci Technol 22(1): 70-75.

ROMANELLI PF \& FELícIO PE. 1999. Jacaré-do-Pantanal (Caiman crocodilus yacare): rendimentos de abate ecomposição da carne. Hig Aliment 13(60): 11-15.

SEIDL AF, SILVA JSV \& MORAES AS. 2001. Cattle ranching and deforestation in the Brazilian Pantanal. Ecol Econom 36(3): 413-425.

SILVA CRS, CAVALCANTE MAT, ALIBONI VL \& PERNA EAM. 2016. Avaliação de rendimento de carcaça suína em relação à carcaça bovina. Revista Intellectus 1(33): 123-134.

SIMONCINI MS, LÁBAQUE MC, PERLO F, FERNANDEZ ME, LEIVA PML, PAEZ AR, TEIRA G, LARRIERA A \& PIÑA Cl. 2020. Caiman latirostris meat characterization: Evaluation of the nutritional, physical and chemical properties of meat from sustainable ranching program in Argentina. Aquaculture 515: 734570.

VICENTE NETO J, BRESSAN MC, FARIA PB, VIEIRA JO, SANTANA MTA \& KLOSTER M. 2006. Composição centesimal e colesterol da carne de jacaré-do-pantanal (Caiman yacare Daudin 1802) oriundo de zoocriadouro e habitat natural. Cienc e Agrotecnologia 30(4): 701-706.

VICENTE NETO J, BRESSAN MC, RODRIGUES EC, KLOSTER MA \& SANTANA MTA. 2007. Avaliação físico química da carne de jacaré-do-pantanal (Caiman yacare Daudin 1802) de idades diferentes. Cienc e Agrotecnologia 31(5): 1430-1434. 


\section{How to cite}

MEDEIROS NBC, RODRIGUES M, MORAIS DH \& NUNES-RODRIGUES MD. 2021. Carcass and commercial cuts yields of caiman (Caiman crocodilus yacare) farmed in a ranching system in the Brazilian Pantanal. An Acad Bras Cienc 93: e20190949. DOI 10.1590/0001-3765202120190949.

Manuscript received on August 28, 2019;

accepted for publication on August 17, 2020

NATALIA B.C. MEDEIROS ${ }^{1}$

https://orcid.org/0000-0001-5233-6639

\section{MARCOS RODRIGUES ${ }^{2}$}

https://orcid.org/0000-0003-3879-6115

\section{DRAUSIO H. MORAIS 3}

https://orcid.org/0000-0002-9866-6008

\section{MARÍLIA D. NUNES-RODRIGUES ${ }^{1,4}$}

https://orcid.org/0000-0003-0008-0912

${ }^{1}$ Grupo de Genética Animal, Universidade Federal Rural da Amazônia/UFRA, PA 275, s/n, Zona

Rural, 68515-000 Parauapebas, PA, Brazil

${ }^{2}$ Professor de Economia Rural, Universidade Federal Rural da Amazônia/UFRA, Instituto Socioambiental e dos Recursos Hídricos/ISARH, Avenida Presidente Tancredo Neves, 2501, Terra Firme, 66077-830 Belém, PA, Brazil

${ }^{3}$ Universidade Federal de Uberlândia/UFU, Instituto de Ciências Agrárias, Km 1, LMG-746, 38500-000 Monte Carmelo, MG, Brazil

${ }^{4}$ Universidade Federal Rural da Amazônia/UFRA, Instituto Socioambiental e dos Recursos Hídricos/ISARH, Laboratório de Genética Aplicada, Avenida Presidente Tancredo Neves, 2501, Terra Firme, 66077-830 Belém, PA, Brazil

Correspondence to: Marília Danyelle Nunes-Rodrigues

E-mail:nunes.mdnunes@gmail.com

\section{Author contributions}

Natalia B.C. Medeiros designed the experiment and carried out the research trial. Natalia B.C. Medeiros and Marcos Rodrigues completed the statistical analyses. Natalia B.C. Medeiros, Marcos Rodrigues, Drausio H. Morais and Marilia D. Nunes-Rodrigues revised the scientific content and drafted the manuscript. Natalia B.C. Medeiros and Marilia D. Nunes-Rodrigues assisted with the experimental design and research trial, while all authors provided editorial suggestions and approved the final manuscript.

\section{(cc) BY}

